\title{
XVI. Yüzyılın İlk Yarısında Manavgat Sancağı ve Sancakbeyleri
}

\author{
Manavgat Sanjak and the Sanjak Governors in the \\ First Half of the $16^{\text {th }}$ Century
}

\begin{abstract}
Saim YÖRÜK*
Öz: Manavgat, II. Murad zamanında son olarak Osmanlı hâkimiyetine girmiştir. Osmanlı döneminde, zamanla değişen şartlar, yaşanan güvenlik kaynaklı sorunlar vb. sebeplerden dolayı XVI. yüzyılda Manavgat'ın idari-statüsü idarî teşkilat ve taksimat açısından önemli değişikliklere uğramıştır. Çalışmada, XVI. yüzyıl başlarında Teke yöresinde çıkan Şahkulu İsyanı öncesinde ve sonrasında Manavgat'ın idarî durumuna değinilmiş, meydana gelen idari değişiklikler sebep - sonuç ilişkisi içerisinde ele alınmıştır. Bu isyan hareketi ile Manavgat ve çevresinde yapılan idari düzenlemeler arasında bağ kurulmuştur. Çalışmada, Manavgat ve çevresine ait tahrir defterleri, eyalet ve sancak tevcih defterleri, kanunnameler, döneme ait kaynak eserler ve Manavgat'ın idari yapısı hakkında bilgi veren çeşitli arşiv vesikaları kullanılmıştır. Bunun yanında idarî yapı ile ilgili genel ve özel anlamda bilgi veren çalışmalardan da yeri geldikçe istifade edilmiştir. Arşiv vesikalarına ve diğer kaynaklara dayanılarak Manavgat Sancağı'nın askerî-idarî görevlileri olan sancakbeylerinin isimleri, görev yılları ve gelirlerine ilişkin bilgiler verilmiştir. Çalışma sonunda, konu ile ilgili olarak değerlendirme yapılmıştır. Çalışmanın Manavgat'ın idari tarihine katkı yapacağı düşünülmektedir.
\end{abstract}

Anahtar sözcükler: Manavgat Sancağı, Sancakbeyi, XVI. Yüzyıl, Şahkulu İsyanı

Abstract: Manavgat became an Ottoman region during the reign of Murad II. In the Ottoman era, the changing conditions and security-related problems, etc., the administration had to affect significant changes in the administrative status, organization and divisions in Manavgat in the $16^{\text {th }}$ century. In this study, the administrative status of Manavgat was discussed, both before and after the Şahkulu Rebellion in the Teke region and administrative changes were addressed based on causality. A correlation is established between the rebellion and the administrative organizations in Manavgat and its vicinity. In this study, cadastral records, provincial and sanjak grant records, regulations, the period resources and various archival documents that provide information about the administrative status of Manavgat were utilized. Further, the works that provided general and specific information on the administrative structure of the sanjak were also employed. The names, the years in the position and salaries of the sanjak governors, who were the military-administrative officers of the Manavgat Sanjak, are provided, from archive documents and other sources. At the end of the study, an assessment of the topic is conducted. This research making a contribution to the administrative history of Manavgat.

Keywords: Manavgat Sanjak, Sanjak Governor, $16^{\text {th }}$ Century, Şahkulu Revolt

\section{Giriş}

Manavgat, II. Murad zamanında son olarak Osmanlı hâkimiyetine girmiştir. Zamanla değişen şartlar, yaşanan güvenlik kaynaklı sorunlar vb. sebeplerden dolayı XVI. yüzyılın ilk yarısında Manavgat’ın idari statüsünde idarî teşkilat ve taksimat açısından önemli değişiklikler olmuştur.

\footnotetext{
* Dr. Öğr. Üyesi, Çankırı Karatekin Üniversitesi, Edebiyat Fakültesi, Tarih Bölümü, Çankırı. saimyoruk@hotmail.com, https://orcid.org/0000-0001-7294-2345
} 
Osmanlı dönemi Manavgat'ın idari yapısını ele alan bilimsel çalışmaların sayısı yok denecek kadar azdır. Manavgat ve çevresi hakkında farklı dönemleri içeren genel ve özel anlamda birkaç çalışma yapılmıştır. Bunlardan Behset Karaca'nın XV. ve XVI. Yüzyıllarda Manavgat Kazası başlıklı çalışması daha çok tahrir defterlerine dayanmaktadır. Yine Karaca'nın Antalya tarihi ile ilgili bir eserde bölüm olarak kaleme aldığı "Dünden Bugüne Manavgat" başlıklı çalışması ile İ. Hakkı Konyalı ve Ali Yıldız'ın Abideleri ve Kitabeleri ile Manavgat Tarihi çalışması Manavgat tarihi hakkında genel ve toplu bilgi vermesi açısından önemlidir (Karaca 2010, 423-446; Konyalı \& Yıldız 2010). Bu çalışmalarda, XVI. yüzyılın ilk yarısı Manavgat'ın idari durumu hakkında teferruatlı bilgi bulunmamaktadır. Manavgat'ın sancak olarak Osmanlı idari teşkilatında yer almasına detaylı bir şekilde ilk defa burada değinilecektir.

XVI. yüzyıl Osmanlı idari taksimatı çeşitli sebeplerle tutulan defterler ve kayıtlar sayesinde tespit edilebilmektedir. Bu konuda bilgi veren kaynakların başında tahrir defterleri gelmektedir. Tahrir defterleri, tımar sistemi uygulanan yerlerde vergi yükümlüsü kişilere ait çeşitli bilgileri içeren sayımları ve bu sayımların kaydedildiği defterleri ifade eder (Öz 2010, 425). Bir bölgenin Osmanlı topraklarına dâhil edilmesinden birkaç yıl sonra ilk tahrir yapılmakta ve daha sonraki yıllarda çeşitli sebeplerle de bu sayımlar yenilenmekteydi. Bu tahrirler sırasında elde edilen bilgiler mufassal, icmal ve evkaf başlıklı farklı defterlere kaydedilmekteydi (Öz 2010, 428).

Osmanlı dönemi Manavgat'ın idari durumu hakkında bilgi veren en eski defter 1455 tarihli olup Osmanlı Arşivi Maliyeden Müdevver Defterler kataloğunda MAD.14 no'lu mufassal tahrir defteridir. Defterde, Teke Sancağı ve Manavgat Subaşılığı'nın köyleri hakkında bilgiler yer almaktadır. Köy isimlerinden yola çıkarak Manavgat'ın sınırlarını yaklaşık olarak belirlemek mümkündür. Bu da defterin kıymetini arttırmaktadır.

Manavgat tarihi hakkında bilgi veren diğer bir kaynak ise MAD.16029 no'lu icmal defteridir. Bu özet tahrirden daha önceleri Manavgat'ın da içerisinde yer aldığı Alâiyye Sancağı'nın ayrıntılı bir tahririnin yapıldı $\breve{g} 1$ anlaşılmakta ise de şimdilik böyle bir defterin varlığı bilinmemektedir. Tahrir kâtibi Hacı Mustafa bin İvaz tarafindan kaleme alınan defter, 16 Mayıs 1475 (10 Muharrem 880) tarihlidir. Defterdeki bazı kayıtlardan 1485 yılına kadar işlem gördüğü anlaşılmaktadır (MAD.16029, 1475, 1; Erdoğru 2013, 14, 23). Söz konusu defter, Alâiyye’nin Osmanlı idaresine geçmesinden sonraki ilk durumu hakkında bilgi vermesi açısından mühimdir. Defterde yer alan köylerin dağılımı sayesinde Manavgat ve Alâiyye Sancağı'nın sınırlarını yaklaşık olarak tespit etmek mümkündür.

Manavgat'ın idari durumu hakkında bilgi veren diğer defter ise MAD.152 no'lu icmal defteridir. Söz konusu defterin düzenlenme tarihi hakkında farklı görüşler bulunmaktadır. Emecen, Varlık ve Kankal söz konusu defterin II. Bayezid devrindeki tahrirlerin sonuçlarını yansıttığı görüşündedirler (Emecen 1989, 7; Varlık 1999, 123; Kankal 2009, 12). Bulduk ise defterde yer alan tımar sahiplerinin ve tımar hâsıllarının çoğunun TD.162 no'lu Kanuni devri başlarına ait icmal defterle benzerlik gösterdiğini ileri sürerek Sultan Süleyman'ın tahta geçiş dönemine ait olabileceğini (Bulduk 2013, XXVI-XXVII); Karaca defterde yer alan tımarlı sipahi isimleri vb. kayıtları dikkate alarak 1520-1530 yıllarını kapsadığını (Karaca 2009, XIX), Ünal ise 1521 tarihinde yapılmış bir tahrire dayalı yoklama defteri olduğunu (Ünal 2014, 3) ileri sürmüştür. Çalışmada Manavgat'ın idari durum bilgisi dikkate alınarak söz konusu defterin II. Bayezid devrinde tutulduğu sonucuna varılmıştır.

Manavgat'ın idari durumu hakkında bilgi veren diğer bir kaynak grubu ise üzerinde beylerbeylerinin ve sancakbeylerinin hasları ile birlikte kaydedildiği listelerdir. Bu listelerin ilki Topkapı Sarayı Arşivi’nde kayıtlı bulunan, düzenlenme tarihi belirtilmeyen 9772 no'lu listedir. Söz konusu liste üzerinde herhangi bir tarihin belirtilmemesi durumunu XVI. yüzyılın başlarına ait diğer bazı listelerde de (TSMA.d. 10057, 5246, 8303 gibi) görmek mümkündür. Bu tür listelerde sancakbeyleri ya da beylerbeylerinin ne zaman o göreve tayin edildikleri, ne zaman 
görevden alındıkları bilgilerini içermemektedir. Bu durum, bu tür listelerin mevcut idari durum hakkında bilgi sahibi olma veya bir üst makama bilgi amaçlı sunulmak maksadıyla düzenlenmiş olabileceğini akla getirmektir. Dolayısıyla listede görevli bulunan kişilerin görev süreleri hakkında, dönemin farklı kaynaklarındaki bilgiler karşılaştırılarak fikir yürütülebilir. Bu listeler üzerinde çalışma yapan araştırmacıların, listedeki bütün görevlilerle ilgili araştırma yapmamasından, sadece araştırma konusu ile ilgili kişi ya da kişiler üzerinde yoğunlaşmasından, dönemin kaynaklarında da yeterli bilgilerin olmaması vb. nedenlerden dolayı söz konusu listelerin düzenlenme tarihi konusunda farklı görüşler ileri sürmüşlerdir. Nitekim Nejat Göyünç, Ö. L. Barkan'ın yayınladığ 19772 no'lu listedeki idari taksimat hakkındaki bilgilerin bu dönemin taputahrir defterlerindeki bilgilere tam uymadığını kaydederek bu defterlerin özel raporlar olarak hazırlanmış olduklarını, bu sebeple resmi belge sayılamayacaklarını, dolayısıyla idari taksimatı göstermek bakımından yeterli olmadıklarını ileri sürmüştür (Göyünç 1969, 34). Kunt ise bu listeler ile tapu-tahrir defterleri arasındaki bilgi farklılığının nedenini, güvenilirlik durumlarından ziyade o devirde sancak düzeninin sürekli değişim içerisinde olmasına bağlamıştır (Kunt 1978, 33). Ö. Lütfi Barkan, 9772 no'lu listenin Kanuni Sultan Süleyman'ın tahta geçtiği ilk yı1lara, 1520 yılına, ait olabileceğini ifade etmiştir (Barkan 2000, 676); Aynı listenin tarihlemesini ise Miroğlu, Akgündüz ve Çakar 1517 yılı olarak yapmışlardır (Miroğlu 1990, 18; Akgündüz 1991, 485-486; Çakar 2003, 357).

9772 no'lu listenin düzenlenme tarihi hakkında Manavgat ile ilgili bilgiler dikkate alınarak tahminde bulunulabilir. Söz konusu listede Manavgat sancakbeyi olarak gözüken Çaşnigir Hüsrev Bey ile Haydar Çelebi'nin Ruznâmesinde geçen Hüsrev Bey aynı kişi olmalıdır. Osmanlı ordusu, Mısır seferi dönüşünde Halep önlerine geldiğinde, 1518 Mart ayı ortalarında (h.924 R. Evvel), Hüsrev Bey’e Manavgat ve Alâiyye zam olunup verilmiştir. Bu bilgiye göre söz konusu liste 1518 Mart ayı ortalarından sonra hazırlanmış olmalıdır.

T. Gökbilgin, TSMA.d. 9578 no'lu Rumeli sancak, şehir ve kasabalar defterini yayınlarken 10057 no'lu listenin Rumeli Beylerbeyliği kısmını da yayınlamıştır (Gökbilgi 1956, 251-253). Kunt, her iki listedeki bilgileri karşılaştırarak 10057 no'lu listenin 1526 Nisan ayı ile 1527 yılı başları arasında hazırlandığını ileri sürmüştür (Kunt 1978, 32-33). Bu sebeple çalışmada söz konusu listenin tarihlemesi 1526 y1lı olarak kabul edilmiştir.

Kunt, 5246 no’lu listenin tarihlemesini ise 10057 no'lu defterle olan yazı benzerliğini ileri sürerek ve ihtiva ettiği bilgileri dikkate alarak 1526 yılı sonları ile 1527 Haziran ayı arasında hazırlandığını ifade etmiştir (Kunt 1978, 33-34). Çalışmada söz konusu listenin tarihlemesi 1527 yılı olarak kabul edilmiştir.

Yine Kunt, 8303 no'lu listenin ihtiva ettiği bilgileri dikkate alarak tarihlemesini 1527 y1lı sonları ile 1531 yılı başları olarak yapmıştır (Kunt 1978, 34). Defterin ihtiva ettiği bilgiler tekrar incelendiğinde bu tarih aralığını biraz daha daraltmak mümkündür. Düzenleme bakımından, diğer listelerde paşa sancağ 1 ve beylerbeyleri yazılmış iken bu listede zikredilmemektedir. $\mathrm{Bu}$ durum listenin düzenlenme tarihinin saptanmasını güçleştirmektedir. 5246 no'lu listede Semendire sancakbeyi olarak Ferhad Ağa'nın oğlu Hüsrev Bey görev yapmaktadır. 8303 no'lu listede ise Semendire sancakbeyi olarak Yahya Paşa oğlu Mehmed Bey gözükmektedir. Mehmed Bey'in ismi bu görevde ilk kez Viyana kuşatması öncesi, 27 Eylül 1529 (23 Muharrem 936) tarihinde (Peçevî İbrahim Efendi 1283, 135; Peçevî İbrahim Efendi, 1999, 103) ve Budin'in ele geçirilmesinden sonra (11 Eylül 1529/7 Muharrem 936) Osmanlı ordusunun Estergon kalesi önlerine gelmeleri sebebiyle geçmektedir (Celalzâde 1981, vrk.188/a; Celalzade 2011, 155). Diğer taraftan 8303 no’lu listede Alacahisar Beyi olarak Hüseyin Bey görünmektedir. Hâlbuki 937 (1530-31) yılındaki Budin kuşatmasında ise Alacahisar beyi olarak Ahmed Bey'in ismi geçmektedir (Peçevî İbrahim Efendi 1283, 157). Bu bilgilere göre 8303 no’lu liste, 1529 yılı ile 1531 yılı başları arasında hazırlanmış olmalıdır. 
Manavgat'ın idari durumu hakkında bilgi veren diğer defter ise İD.107 no'lu icmal defteridir. Söz konusu defter üzerinde ne zaman ve kimler tarafından tutulduğuna dair bilgi bulunmamaktadır. Defter, 5 Mart 1521 - 12 Ağustos 1535 tarihleri arasındaki tımar tevcihlerini kapsamaktadır. Karaca, kayıt tarihlerinin 1523-24 ila 1528-29 yıllarında yoğunlaştığını, bu sebeple defterin 1520-1522 yılları arasında tutulmuş olabileceğini iddia etmiş ve defterin tarihlemesini 1520 (h.927) olarak yapmıştır (Karaca 2009, XVIII-XIX). Konyalı ise çalışmasında 107 numaralı İcmal defterinin tarihlemesini 1520 (h.927) yılı olarak yapmıştır (Konyalı 2011, 382, 485).

Osmanlı Arşivi'nde bulunan 1530 tarihli TT.166 no'lu icmal defterinde Anadolu Vilayetinin sancaklarına dair kayıtlar yer almaktadır. Alâiyye Sancağı ve Manavgat'ın idari durumu hakkında bilgiler ise defterin 613-628. sayfalarındadır.

\section{Osmanlı İdari Teşkilatında Manavgat}

II. Murad zamanında kesin olarak Osmanlı hâkimiyetine giren Manavgat, Osmanlı hâkimiyetine girmesinden sonra idarî teşkilat ve taksimat açısından önemli değişiklikler geçirmiştir. Manavgat'ın XVI. yüzyılın ilk yarısındaki idari durumu arşiv kayıtlarından öğrenilmektedir. 1455 tarihli tahrirde Manavgat ayrı bir subaşılık olarak Teke Sancağı ile birlikte kaydedilmiştir (MAD.14, 1455, vrk.156/a-227/a, 383/a-410/a, 435/a-436/a; Karaca 2009, 26).

Manavgat, 1471 yılında Alâiyye'nin fethi ile nahiye haline getirilerek buraya bağlanmıştır (MAD.16029,1475, 43; Erdoğru 2013, 25, 28). II. Bayezid devrinde yapilan tahrirlerin genel sonuçlarını gösterdiği tahmin edilen bir icmal defterine göre de Manavgat, Alâiyye Sancağı'nın nahiyesi durumundadır (MAD. 152, vrk.148/a-150/b).

Alâiyye Sancağı'na ait, muhtemelen II. Bayezid veya Yavuz Sultan Selim dönemine (Akgül 1989, XXIX; Konyalı 2011, 247) veya 1501-1502 yıllarına ait (Karaca 2009, XVIII), baş kısmı eksik ve tarihsiz TD. 990 no'lu tahrir defterinde yer alan nahiyeler içinde Manavgat bulunmamaktadır. Manavgat'a ait bilgilerin ise defterin bu eksik kısımda yer aldığı düşünülmektedir.

XVI. yüzyıl başlarında Manavgat'ın idari durumu hakkına bilgi veren diğer bir kaynak ise Topkapı Sarayı Arşivi'ndedir. Söz konusu kaynak, 1513 (h.919) tarihli bir defterdir. Defterde Anadolu Vilâyetinde yer alan her sancağın kazaları yazılmış, kadıları belirtilmiş ve akçe olarak gündelikleri gösterilmiştir. Deftere göre Manavgat kadısı Mevlana Akbaş Emin olup bu görevde asaleten bulunmakta ve günlük 40 akçe almaktadır (TSMA.d.929 (1513), vrk.7/b; Gökçe 1994, 248, 258).

1513 yı1ı idari taksimatı, önceki yıllardaki idari yapı ile karşılaştıııldığında bazı farklılıklarının olduğu görülmektedir. Önceki yıllara ait defterlere idari birim açısından nahiyeler kaydedilmiş iken 1513 tarihli defterde kazalar dikkate alınmıştır. Buna göre söz konusu sancak, idari bakımdan Alâiyye Sancağı; Alâiyye, Akseki ve Manavgat olmak üzere üç ayrı kaza halinde kaydedilmiştir. Kazaların nahiye taksimatı hakkında ise bilgi verilmemiştir.

\section{Manavgat'ın Sinırları}

XVI. yüzyıl Osmanlı idari teşkilatına göre Manavgat'ın tamamı günümüz Akdeniz Bölgesi sınırları içerisinde yer almaktadır. Tapu tahrir defterlerinde yer alan köylerin dağılımından Manavgat'ın sınırlarını yaklaşık olarak tespit etmek mümkündür. İdarî taksimat bakımından Manavgat, batıda Köprüçay ile Teke Sancağı'nın Karahisar-1 Teke kazasından ayrılmaktaydı (VGMA. 596 no'lu defter, h.982/m.1574, 67). Kuzeydoğu sınırını Akseki kazası ve onun köyleri oluşturmakta yani Manavgat Çayı, Manavgat ile Akseki arasında doğal sınır oluşturmaktaydı. Yine kuzey ve kuzey doğusundaki İbradı, Manavgat kazasının sınırları içerisinde yer almaktaydı. Ayrıca daha kuzeydeki dağlar içerisinde yer alan ve günümüzde Konya'ya bağlı Derebucak, Gencek ve çevresi de, 1914 y1lı idari taksimat çalışmalarına kadar, Manavgat kazasının sınırları içerisindeydi (MAD. 14, h.859/m.1455, vrk.166/a; TTD. 172, 1555, vrk.9394; Akgül 1989, 175-176; DH.I.UM.EK. 90/70 (ek.31/01), 1914); Selekler 2011, 69-70, 77-78). Kuzeydeki bu dağlar, Beyşehir Sancağı'nın Kaşaklı ve Yağan nahiyeleri ve Hamid Sancağı top- 
rakları arasında doğal bir sınır teşkil etmekteydi. Doğu sınırı ise Manavgat Çayı ile son bulmakta ve çayın doğu kısmı, Alâiyye kazasının sınırları içerisinde yer almaktaydı. XVI. yüzyılda Manavgat Çayı'ndan Alara Çayı'na kadar sahile yakın ovalık ve kısmen tepelik olan yerler Karacalar nahiyesi, kıyıdan biraz içeride Ahmedler ve Gebece köylerinin bulunduğu tepelik ve dağllk kesim ise Çöngere nahiyesi olarak bilinmekteydi (BOA 1995, 193; Erdoğru 1998, 27, 34, 324; Karaca 2009, 8, 35-36, 43). Kısacası Manavgat'ın idari sınırlarını coğrafi olarak doğu-batı istikametinde Köprüçayı ile Manavgat Çayı arasındaki alan oluşturmakta, kuzeyinde bulunan dağlar sınırı teşkil etmekteydi. Güneyinde ise bilindiği üzere Akdeniz yer almaktadır. Manavgat'ın sınırlarının belirlenmesinde fizikî unsurların yani coğrafî şartların birinci derecede etkili olduğu anlaşılmaktadır.

\section{Şahkulu İsyanı ve Manavgat}

XVI. yüzyılın başlarından itibaren Osmanlı Devleti’nin karşılaştığı en önemli meselelerden birisi, Anadolu'da özellikle de Teke-ili ve Hamid-ilinde yaşanan geniş çaplı sosyal çalkantıların olmasıdır. Safevi Devleti veya Safevi tarikatıyla bir şekilde irtibatı bulunanlar bazı olaylara neden olmuşlardır. II. Bayezid döneminde, Teke yöresinde yaşayan bazı Şii ve Alevi Türkmenler, isyan hareketine kalkışmışlardır. Bu isyanlardan en önemlisi 1511 yılındaki Şahkulu İsyanı olup daha çok Teke ve Hamid-ilinde etkili olmuştur. Bu çalkantılar ve problemler, devleti ve halkı derinden etkilemiş, bölgede silinmesi zor izler bırakmıştır. Devlet, benzer olayların tekrar yaşanmaması için bazı tedbirler almak zorunda kalmıştır. Bu tedbirlerden birisi şekavette bulunan, isyan ve karışıklıklar çıkaran konar-göçerleri sürgün etmek olmuştur. Anadolu'da 50.000 kişinin ölümüne sebep olan bu isyan ve ardından yapılan sürgünler, kendi istekleriyle İran'a giden halk nedeniyle, Hamid ve Teke sancaklarında nüfus azalmış, belli başlı kaza ve nahiyeler küçülmüş, birçok köy boşalarak mezraya dönüşmüştür (Erten 1340, 98-99; Tekindağ 1967, 34-39; I/4, 1968, 54-59; 1979, 126-128; Sümer 1976, 36; Armağan 1998, 13; Karaca 2002a 46-51; 2002b, 413-415; 1999, 649-652; 2017, 580-582; Emecen 2015, 521-534). Bu durum, Hamid ve Teke sancaklarında yapılan sürgünlerin ve göç hareketinin oldukça geniş kapsamlı olduğunu göstermektedir. Bu tür heterodoks eğilimler sebebiyle olsun veya isyan ve fesat ehlini cezalandırmak amacıyla olsun yapılan bu göç ve sürgünler, Manavgat ve çevresinin demografik yapısında da değişikliklere neden olmuştur.

XVI. yüzyılın başlarında yaşanan bu olaylardan Manavgat'ın idari yapısı da etkilenmiştir. Muhtemelen, yaşanan bu olayların etkisiyle Manavgat, sancak haline getirilmiştir. Manavgat'in ne zaman ve hangi sebeplerle sancak yapıldığına dair kaynaklarda bilgi bulunmamaktadır. Bu konu ile ilgili ilk bilgi Yavuz Sultan Selim'in Mısır seferi sırasında karşımıza çıkmaktadır. Osmanlı ordusu, 31 Temmuz 1516 (1 Recep 922) tarihinde Elbistan'da konakladığında Anadolu kethüdalığından azledilmiş olan Hasan Bey, Manavgat sancakbeyi olarak tayin edilmiş ve Malatya'yı muhafaza etmekle görevlendirilmiştir (Feridun Bey 1274, 478; Haydar Çelebi 1984, 184; Seslikaya 2014, 146). Hasan Bey, Manavgat'in bilinen ilk sancakbeyidir. Daha önce bu görevde kim ya da kimlerin bulunduğu hakkında kaynaklarda yeterli bilgi bulunmamaktadır. Misır seferi dönüşünde de ordu Halep önlerine geldiğinde 1518 Mart ayı ortalarında (924 R.Evvel ay1) ise Hüsrev Bey'e Manavgat ve Alâiyye zam olunup verilmiştir (Feridun Bey 1274, 497; A. Seslikaya 2014, 177).

Aynı dönemde başka kaynaklarda Manavgat'ın sancak olduğunu gösteren bilgiler de bulunmaktadır. Düzenlenme tarihi belirtilmeyen, ancak 1518 yılı Mart ayı sonrasında düzenlendiğini tahmin ettiğimiz sancakların ve sancakbeylerinin isimlerinin yazılı olduğu listede Vilâyet-i Anadolu başlı̆̆ı altında Anadolu Vilayeti'nin 19 sancağı bulunmaktadır. Manavgat da bu sancaklar arasında yer almaktadır. Manavgat'ın dışındaki diğer sancaklar Saruhan, Kütahya, Aydın, Bolu, Menteşe, Teke, Ankara, Hüdavendigar, Kastamonu, Kengiri (Çankırı), Hamid, Karasi, Karahisar, Alâiyye, Biga, Sultan-önü, Koca-ili ve Trabzon’dur (TSMA.d. 9772, 1518?, 
vrk.2/b-3/a; Barkan 2000, 677). Aynı listeye göre Manavgat sancakbeyi olarak Çaşnigir Hüsrev Bey görev yapmaktadır (TSMA.d.9772, 1518?, vrk.2/b).

$\mathrm{Bu}$ bilgilere göre bölgede yaşanan olaylar sebep-sonuç ilişkisi içerisinde ele alındığında Şahkulu İsyanı ve devamında gelişen olayların etkisi ile Alâiyye Sancağı'nın idari taksimatında düzenlemeye gidildiği ve Manavgat'ın idari statüsünde değişiklik yapılarak ayrı bir sancak haline getirildiği anlaşılmaktadır. İdari yapıda böyle bir değişikliğe gidilmesinde, muhtemelen, yeni bir Şahkulu İsyanı'nın ortaya çıkmasını engelleme, konar-göçerleri daha etkin bir idare ile kontrol altında tutma anlayışı da etkili olmuştur.

Manavgat'ın idari durumu hakkında dönemin kanunname mecmualarında da bilgiler bulunmaktadır. Kanuni Sultan Süleyman'ın ilk dönemlerinde düzenlenmiş, 1522 (h.928) tarihine ait bir kanunname mecmuasında Osmanlı topraklarının hem sancak hem de kaza taksimatı hakkında bilgi verilmektedir (Kanunnâme 1522, vrk.112/a-118/a). Söz konusu kanunname mecmuasındaki sancak listesinde verilen bilgilere göre Anadolu Eyaleti, paşa sancağı ile beraber toplam 17 sancaktan meydana gelmektedir. Anadolu Eyaleti'nin sancakları Kütahiyye, Teke, Aydın, Ankara, Saruhan, Menteşe, Karahisar, Bolu, Kastamonu, Hüdavendigar, Karasi, Kangırı, Hamid, ‘Alâiyye maa Manavgad, Biga, Koca-ili, Sultan-önü’dür (Kanunnâme 1522, vrk.119/b; Çakar 2002, 261-282). Bu listede dikkat çeken nokta ise Manavgat'ın ayrı bir sancak olarak kaydedilmemiş olmasıdır. Kanunname mecmuasında Manavgat, Alâiyye ile birleştirilerek Alâiyye maa Manavgâd adıyla bir sancak olarak kaydedilmiştir. Listede sancakbeyi olarak ise İskender Bey’in ismi geçmektedir (Kanunnâme 1522, vrk.119/b). Bu bilgilere göre, 1518 tarihli olduğunu tahmin ettiğimiz listeden farklı olarak, 1522 yılından evvel Manavgat, Alâiyye ile birleştirilmiş, ikisi bir sancak haline getirilerek Anadolu Eyaleti'ne bağlanmıştır. Taht değişikliği ve bu sırada ortaya çıkan iç isyanlar dikkate alındığında, her iki sancağın birleştirilmesi 1520 yılından sonra olmalıdır. Manavgat Sancağı'nın Alâiyye ile birleştirilerek bir sancak olarak teşkilatlandırılmasında Manavgat'ın, Teke Sancağı ile Alâiyye Sancağı arasında Alâiyye sancağı toprakları ile bir bütünlük arz etmesi, bölgede yaşanan asayiş ve güvenlik kaynaklı sorunların büyük ölçüde giderilmesinin etkili olduğu düşünülmektedir. Böyle bir idari değişikliğin olmasında bölgenin coğrafi, ekonomik ve demografik yapısı da dikkate alınarak devlet otoritesinin daha kuvvetli hissettirilmesi, etkili bir yönetimin kurulması amaçlanmış olmalıdır.

Söz konusu kanunnamede dikkat çeken diğer bir nokta ise sancak listesinde Manavgat, Alâiyye ile birlikte bir sancak olarak kaydedilmiş iken kaza listesinde sadece Alâiyye Sancağ isminin geçmesidir. Sancak listesinde Alâiyye Sancağı yazılır iken Manavgat unutulmuş, sonradan Alâiyye kaydının üzerine daha küçük harflerle maa Manavgat şeklinde kaydedilmiştir. Bu durum, kaza listesinin kaydı sırasında Manavgat isminin unutulmasından kaynaklanmış olmalıdır.

Sancakbeyleri ve beylerbeyleri haslarının da kaydedildiği 1526 tarihli sancak tevcih defterinde Manavgat'ın ismi geçmemektedir. Bir önceki kanunnamede birlikte kaydedildiği Alâiyye, Livâ-yı Alâiyye adıyla Anadolu Beylerbeyliğinin sancakları arasındadır. Listede sancakbeyi olarak ise Yakup Ağa'nın biraderi Sinan Bey'in ismi geçmektedir (TSMA.d.10057, 1526?, vrk.4/a). 1527 tarihli başka bir sancak tevcih defterinde ise Manavgat yine Alâiyye ile birlikte, Livâ-yı Alâiyye ve Manavgad adıyla Anadolu Beylerbeyliği'nin sancakları olarak gözükmektedir. Listede sancakbeyi olarak Yakup Ağa'nın biraderi Sinan Bey'in ismi geçmektedir (TSMA.d.5246, 1527?, vrk.4/a). Her iki defter karşılaştırıldığında, bilgiler aynı olmakla birlikte, 1526 tarihli defterde Manavgat ismi geçmemektedir. 1526 tarihli defterde Manavgat isminin Alâiyye ile birlikte geçmemesi, 1527 tarihli defter dikkate alındığında, Manavgat isminin kâtip tarafindan unutulduğu izlenimini vermektedir.

1529-1531 yılı başları arasında tutulduğu tahmin edilen bir sancak defterinde de Manavgat, Livâ-yı Alâiyye maa Manavgad adıyla Anadolu Eyaleti'nin sancakları arasındadır. Defterde sancakbeyi olarak Abdüssamed Bey gözükmektedir (TSMA.d.8303, 1529-1531 yılı başları, 
vrk.2/b). 1529-1530 yıllarına ait bilgileri de içeren 107 no'lu İcmal defterinde ise Abdüssamed Bey Alâiyye sancakbeyi olarak gözükmektedir (ID.107, 236). Tasarruf edilen akçe miktarı ile tarihleri dikkate alındığında her iki defterde sancakbeyi olarak ismi geçen Abdüssamed Bey aynı kişi olmalıdır.

Manavgat'in idari durumu hakkında ileri tarihli tahrir ve icmal defterlerinde de bilgiler bulmak mümkündür. Nitekim 1530 tarihli Muhasebe İcmal Defterinde sancak olarak Manavgat geçmemekte, sadece Alâiyye geçmektedir. Alâiyye, Anadolu Eyaleti'ne bağlı 17 sancaktan biridir. 1530 tarihli icmal defterine göre Alâiyye Sancağı iki kazadan meydana gelmekte olup bunlar Alâiyye ve Manavgat'tır (BOA 1995, IX, 613, 623). 1530 yılından XVI. yüzyıl sonlarına kadar Manavgat'ın kaza statüsünde herhangi bir değiş̧iklik olmamıştır. (TTD. 172, 1555, vrk. 90, 120, 121; İD. 363, 1555, vrk. 4, 6, 13-21; Akgül 1989, XXV, 171, 210, 212, 227-228, 232, 246-255; Baykara 2000, 179; Yörük 2012, 270-291).

Arşiv vesikalarında yer alan bilgiler dikkate alındığında, Manavgat'ın Alâiyye ile birlikte sancak statüsünün uzun sürmediği anlaşılmaktadır. 1520'li yılların başından itibaren başlayan Manavgat'ın Alâiyye ile bir olan sancak statüsü fazla sürmemiş ve 1530 y1lından itibaren Manavgat, Alâiyye Sancağı'nın bir kazası haline gelmiştir. XVI. yüzyıl sonlarına kadar idari yapıda önemli bir değişikliğin yaşanmaması dikkate alındığında Manavgat ve çevresinde asayiş ve huzurun hâkim olduğu, bölge halkını derinden etkileyecek ekonomik ve sosyal olayların yaşanmadığı anlaşılmaktadır.

\section{Sancak Yönetimi ve Manavgat Sancakbeyleri}

Klasik dönemde Osmanlı taşra teşkilatında temel idarî birim olan sancağın en yüksek yöneticisi, doğrudan merkezden atanan sancakbeyidir. Sancakbeyleri, önceleri belirli bir bölgedeki tımarlı sipahilerin komutanı olarak ortaya çıkmış, daha sonra bu bölgenin idarî özellikler kazanmasıyla gelişen idarî mekanizmanın da başına geçmiştir (Kunt 1978, 26). Askerî sınıfa mensup olan sancakbeyleri, sancakta padişahın yürütme gücünü temsil eden en yüksek yöneticidir. Ancak sancakbeylerinin yetki ve otoriteleri, bağlı bulundukları beylerbeyleri ve doğrudan merkezden emir alan kadılar vasıtasıyla sınırlandırılmıştır (Kunt 1978, 26; İnalcık 2005, 108). Bu şekilde Osmanlılar, taşra yönetiminde adil bir yönetimin temeli olarak kuvvetler ayrılığı ilkesini uygulamışlar ve idarede denge siyasetini izlemişlerdir.

Ehl-i örf sınıfından olan sancakbeyleri kul sisteminden yetişmiş, bağlılıkları daha önceki görevlerinde denenmiş, devlete ve padişaha yararlılıklarından dolayı yükseltilerek bu görevlere getirilmişlerdir (Ergenç 1995, 65). Sancakbeylerinin askerî ve idarî olmak üzere iki aslî görevi vardır. Askerî görevi, kapı halkı ve emrindeki tımarlı sipahiler ile birlikte daima sefere hazır beklemek ve çağrıldığında sefere katılmaktan oluşmaktaydı. İdarî görevi ise reayanın güvenliğini ve düzenini sağlamaktı. Kadı ile ortak hareket ederek bu görevleri yerine getirmekteydi (Yücel 1974, 666; Ergenç 1995, 68).

İncelenen döneme ait arşiv vesikalarından ve diğer kaynaklardan elde edilen bilgilere göre, tespit edebildiğimiz kadarıyla, Manavgat Sancakbeyliği görevinde bulunanlar, görev yılları ve tasarruf ettikleri dirlik miktarı şöyledir:

Tablo 1. Manavgat Sancakbeyleri

\begin{tabular}{|l|l|l|l|}
\hline Sancakbeyi & Görevde bulunduğu yıl & Tasarrufu (Akçe) & Açıklama \\
\hline Hasan Bey & 31 Temmuz 1516 - Mart 1518 & - & Müstakil sancak \\
\hline Hüsrev Bey / & Mart 1518 - ? & - & Alâiyye ile birlikte \\
\cline { 2 - 4 } Hüsrev Bey (Çaşnigir) & $1518 ?$ & 160.000 & Müstakil sancak \\
\hline İskender Bey & 1522 & 222.000 & Alâiyye ile birlikte \\
\hline Sinan Bey & $1526-1527$ & 330.000 & Alâiyye ile birlikte \\
\hline Abdüssamed Bey & $1529-1530$ & 200.000 & Alâiyye ile birlikte \\
\hline
\end{tabular}


Hasan Bey: Hasan Bey, Yavuz Sultan Selim'in Misır seferi sırasında sancakbeyi olarak tayin edilmiştir. Osmanlı ordusu, 31 Temmuz 1516 (1 Recep 922) tarihinde Elbistan'da konaklad1ğında Anadolu kethüdalığından azledilmiş olan Hasan Bey, Manavgat sancakbeyi olarak tayin edilmiş ve Malatya'yı muhafaza etmekle görevlendirilmiştir (Feridun Bey 1274, 478; Haydar Çelebi 1984, 184; Seslikaya 2014, 146). Hasan Bey, Manavgat'ın bilinen ilk sancakbeyidir. Daha önce bu görevde kim ya da kimlerin bulunduğu hakkında dönemin kaynaklarında yeterli bilgi bulunmamaktadır. Hasan Bey'den sonra yerine Hüsrev Bey tayin edilmiştir.

Hüsrev Bey: Mısır seferi dönüşünde de ordu Halep önlerine geldiğinde 1518 Mart ayı ortalarında (924 R.Evvel ayı) ise Hüsrev Bey'e Manavgat ve Alâiyye zam olunup verilmiştir (Feridun Bey 1274, 497; Seslikaya 2014, 177). 9772 no'lu defterde Çaşnigir unvanıyla kayıtlı olup Manavgat sancakbeyi olarak ismi geçmekte ve 160.000 akçe tasarruf etmektedir (TSMA.d.9772, 1518?, vrk.2/b; Barkan 2000, 677). Alâiyye sancakbeyi ise 170.000 akçe ile Mehmed Bey olup Sinan Paşa'nın akrabasıdır (TSMA.d.9772, 1518?, vrk.2/b; Barkan 2000, 677). Çaşnigir Hüsrev Bey, Manavgat'tan sonra Antakiyye sancakbeyliğine tayin edilmiş olup 1522 y1lında 255.000 akçe tasarruf etmektedir (Kanunnâme 1522, vrk.121/a). Söz konusu listede Manavgat sancakbeyi olarak gözüken Çaşnigir Hüsrev Bey ile Haydar Çelebi'nin Ruznâmesinde geçen Hüsrev Bey aynı kişi olmalidır.

İskender Bey: 1522 (h.928) tarihli kanunname mecmuasına göre İskender Bey, Alâiyye maa Manavgâd sancakbeyi olup 222.000 akçe tasarruf etmektedir (Kanunnâme 1522, vrk.119/b). Bu bilgilere göre, 1518 tarihli olduğu tahmin edilen listeden farklı olarak, 1522 yılından evvel Manavgat ile Alâiyye birleştirilerek bir sancak olarak teşkilatlandırıldığı ve İskender Bey'in sancakbeyi olarak tayin edildiği anlaşılmaktadır.

Sinan Bey: Sinan Bey, devlet büyüklerinden Yakup Ağa'nın kardeşidir. 1526-1527 yıllarında, 330.000 akçe ile Manavgat ile birlikte Alâiyye sancakbeyiliği görevinde bulunmuştur (TSMA.d.10057, 1526?, vrk.4/a; TSMA.d.5246, 1527?, vrk.4/a; Kunt 1978, 127). Bu görevini devam ettirir iken Kalender Çelebi İsyanı sırasında Tokat taraflarında Cincife'de 8 Haziran 1527 (8 Ramazan 933) tarihinde asiler ile yapılan savaşta şehit düşmüştür (Celalzâde 1981, vrk.166/b; 2011, 133; İlgürel 2001, 249). Sicill-i Osmanî'de ise unvanı paşa olarak geçmektedir. Ayrıca II. Bayezid'e 1495-1596 yıllarında (h.901) büyük hizmeti geçtiği ve terfi ederek Kapıcıbaş1 olduğu, Mısır'ın fethi senesinde (1517) Sipahiler ağası olduğu, sonra Alâiyye sancakbeyi olarak 1526'da (h.932) İran harbinde şehit düştüğü bilgisi yer almaktadır (Mehmed Süreyya 1311, 105; 1996, 1511). Yerine Abdüssamed Bey tayin edilmiştir.

Abdüssamed Bey: Daha önce bahsi geçtiği üzere, 1529-1531 yıllarına tarihlenen 8303 no’lu sancak listesine göre Livâ-yı Alâiyye maa Manavgad sancakbeyi olarak Abdüssamed Bey görev yapmakta ve 200.000 akçe tasarruf etmektedir (TSMA.d.8303, 1529-1531 yılları?, vrk.2/b; Kunt 1978, 34). 1529-1530 yıllarına ait bilgileri de içeren 107 no'lu İcmal defterinde ise Abdüssamed Bey 200.146 akçe tasarruf etmekte ve Alâiyye sancakbeyi olarak gözükmektedir (IDD.107, 236). Tasarruf edilen akçe miktarları ile tarihler dikkate alındığında her iki defterde sancakbeyi olarak ismi geçen Abdüssamed Bey aynı kişi olmalıdır.

Gerek arşiv belgeleri ve gerekse diğer kaynaklar üzerindeki incelemeler sonucunda, Manavgad Sancağı'nda ve Alâiyye maa Manavgad Sancağı'nda görev yapan sancakbeylerinin isimleri ve görev yılları, tabloda da görüldüğü üzere, belirlenmiştir. Tabloda yer alan bilgilere göre sancakbeylerinin genellikle 1,5-3 yıl gibi sürelerle görev yaptıkları anlaşılmaktadır. Bunların çoğu Alâiyye maa Manavgad sancakbeyi olarak görev yapmıştır. Sancakbeylerinden isimleri tespit edilenlerin 160.000 ila 330.000 akçe arasında dirlik tasarruf ettikleri anlaşılmaktadır. Bu dönemde sadece Hasan Bey'in ne kadar dirlik tasarruf ettiği ise tespit edilememiştir. 


\section{Sonuç}

Çalışmada, XVI. yüzyılın ilk yarısında Manavgat'ın idari yapısında meydana gelen değişiklikler ele alınmıştır. XVI. yüzyıl başlarında Manavgat, idari statü olarak Alâiyye Sancağı'nın bir nahiyesidir. XVI. yüzyılın başlarında bölgede yaşanan karışıklıklar sebebiyle idari yapıda değişikliğe gidilerek, kısa süreli de olsa, Manavgat önce kaza olmuş, daha sonra sancak olarak (15141520 ?) teşkilatlandırılmıştır. Manavgat'ın müstakil sancak statüsü uzun yıllar devam etmemiş, 1520'li yılların başından itibaren Alâiyye ile birleştirilerek bir sancak itibar olunmuştur. Bu durum dönemin kaynaklarına Livâ-yı Alâiyye maa Manavgâd adıyla geçmiştir. 1530 yılında ise Manavgat, Alâiyye Sancağı'nın bir kazasıdır. 1530 yılında Manavgat'ta kurulan bu idari yapı, XVI. yüzyıl sonlarına kadar önemli bir değişikliğe uğramadan devam etmiştir.

XVI. yüzyılın ilk yarısında Manavgat'ın Alâiyye Sancağı'ndan ayrılarak müstakil bir sancak olarak teşkilatlandırılmasında 1511 yılında bölgede yaşanan Şahkulu İsyanı etkili olmuştur. İsyan sebebiyle bölgede güvenlik bozulmuş, asayişin sağlanmasında bazı zorluklarla karşılaşılmıştır. Asilerin vermiş olduğu zararın azaltılması, bölgede yaşanan sosyal ve ekonomik vb. sıkıntıların giderilmesi, bunun yanında bölgede etkin bir idarenin sağlanması, asayiş ve güvenlik kaynaklı endişelerin giderilmesi amacıyla Manavgat'ın, Alâiyye Sancağı'ndan ayrılarak müstakil bir sancak olarak teşkilatlandırıldığı anlaşılmıştır.

Sonuç olarak bu çalışma ile XVI. yüzyılın ilk yarısında Manavgat'ın idari yapısında meydana gelen değişiklikler ortaya konulmuştur. Bu değişikliklerin yaşanmasında, Osmanlı Devleti genelinde ve bölgede yaşanan siyasi, idari ve ekonomik kaynaklı olayların etkili olduğu anlaşılmıştır. Osmanlı döneminde yapılan bu idarî düzenlemelerde bölgede huzur ve güvenliğin sağlanması ve daha etkin yönetimin amaçlandığı sonucuna varılmıştır. 


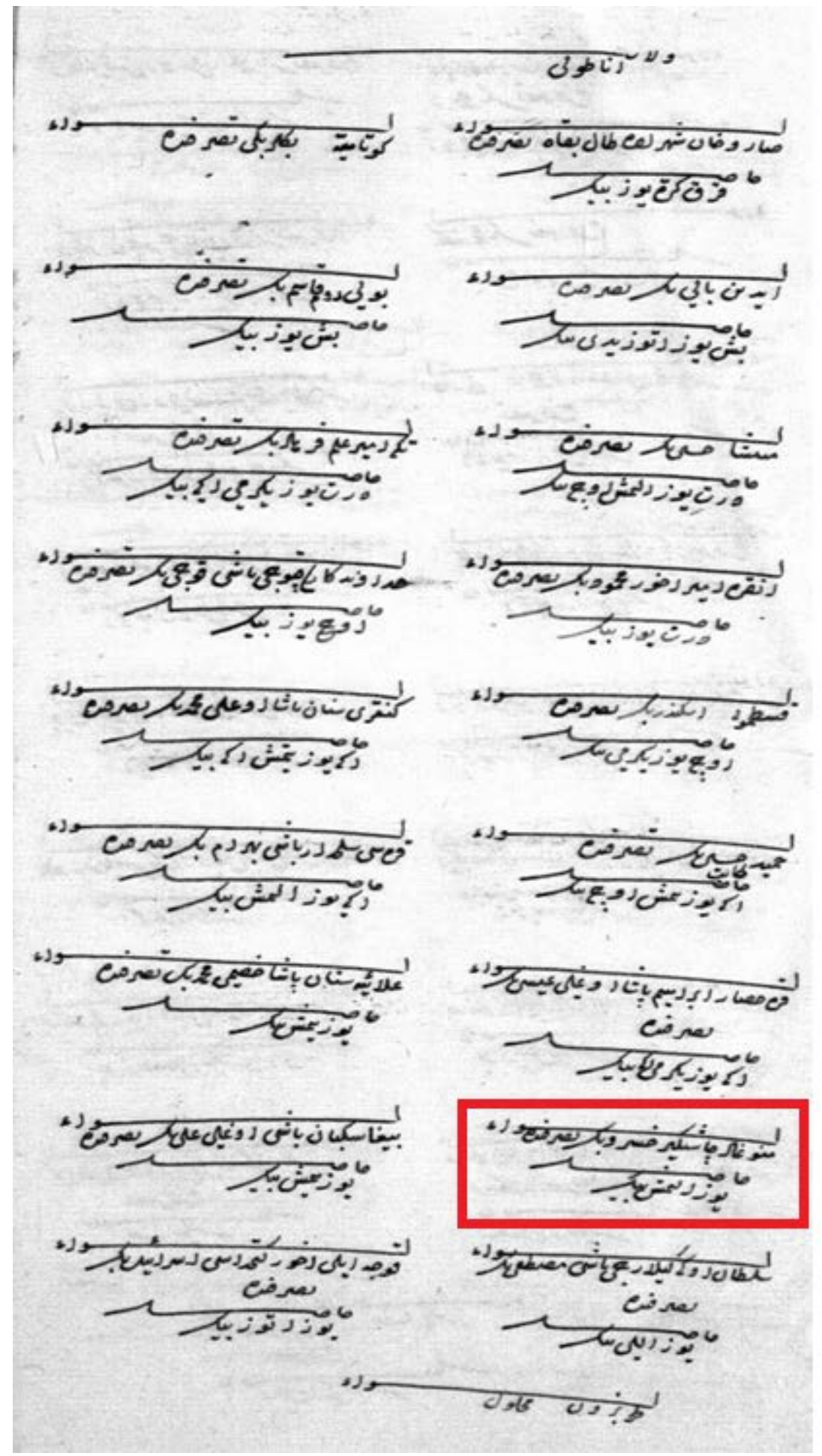

Ek 1. Anadolu Vilâyeti ve Manavgat Sancağı Görevli Listesi (TSMA.d. 9772, vrk.2/b 


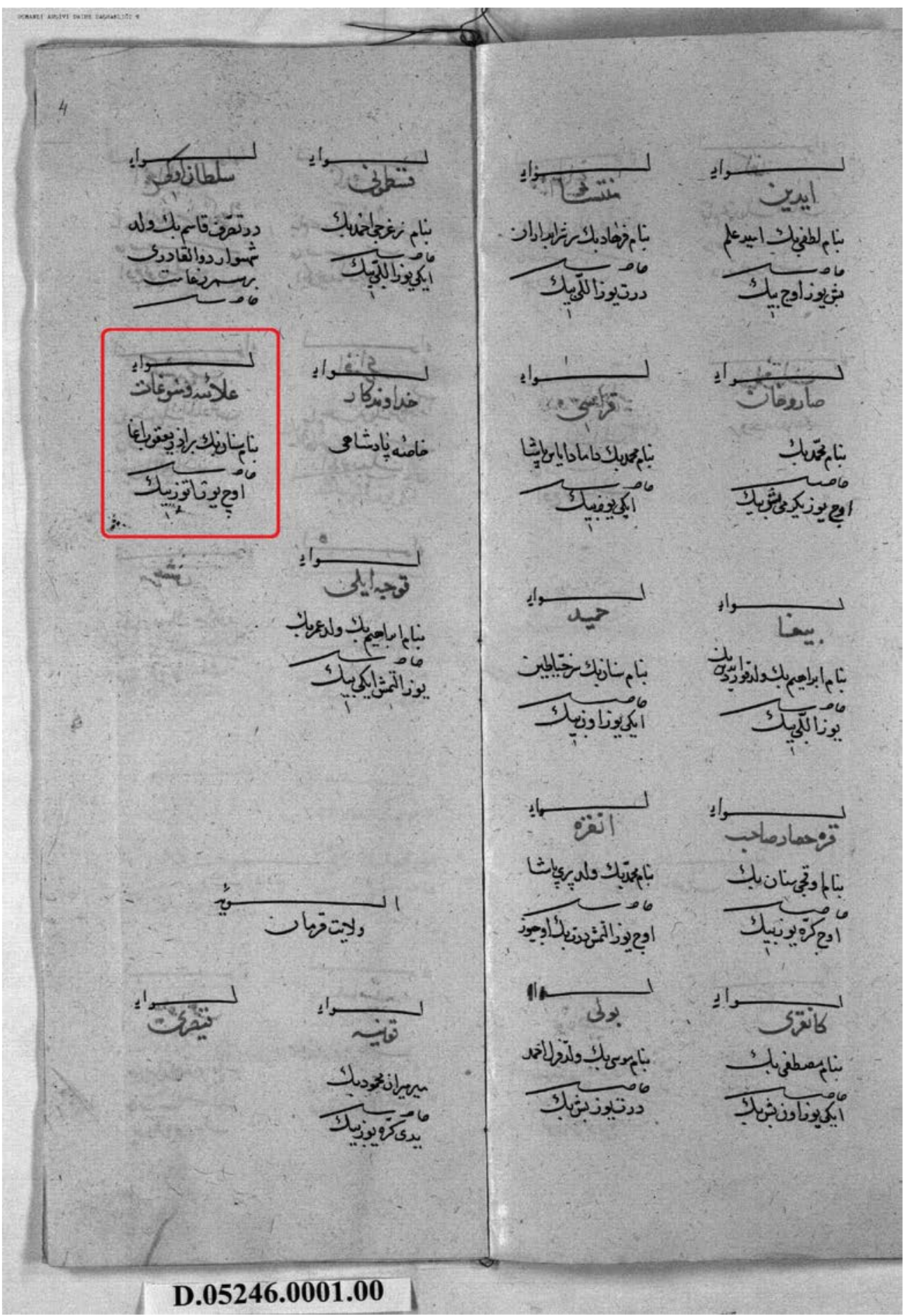

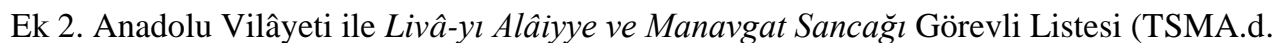
5246, vrk. 3/b-4/a) 


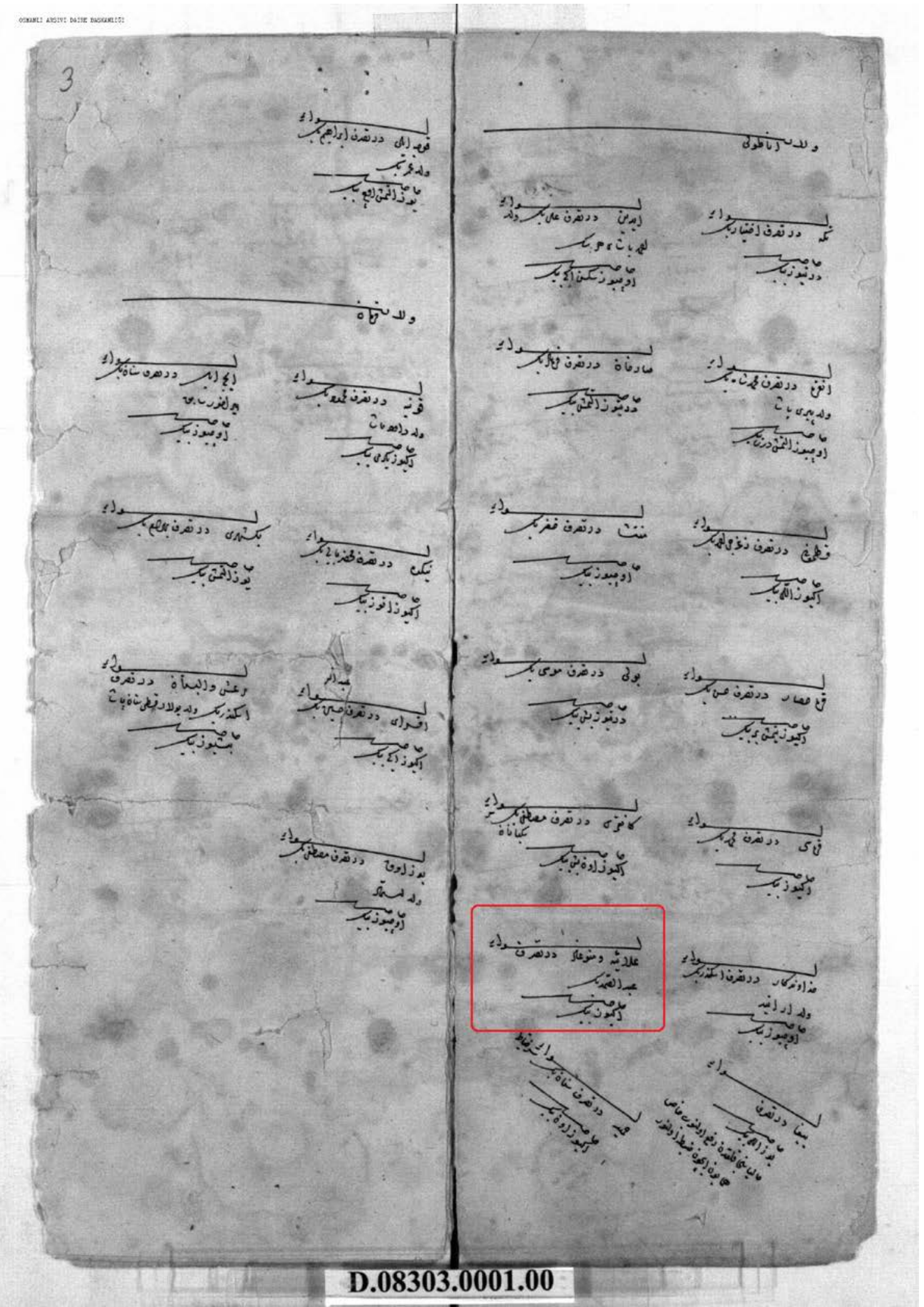

Ek 3. Anadolu Vilâyeti ile Livâ-yı Alâiyye ve Manavgat Görevli Listesi (TSMA.d. 8303, vrk. 2/b-3/a) 


\section{KAYNAKÇA}

\section{Arşiv Kaynakları}

1.1. Devlet Arşivleri Başkanlığı Osmanlı Arşivi (BOA.)

1.1.1.Tapu Tahrir ve İcmal Defterleri (TD.-ID.):

İD.107.

TD.990 (1501-1502?).

1.1.2.Maliyeden Müdevver Defterler (MAD.):

MAD.14 (1455/h.859).

MAD.152.

MAD.16029 (1475 tarihli).

1.1.3.Arşiv Belgeleri:

DH.I.UM.EK.90/70 (ek.31/01), 30 Haziran 1914 (17 Haziran 1330) tarihli irade-i seniyye.

1.1.4.Topkapı Sarayı Arşivi Defterleri (TSMA.d.):

TSMA.d.10057 (1526 tarihli?).

TSMA.d.5246 (1527 tarihli?).

TSMA.d.8303 (1529-1531yilı başları).

TSMA.d.929 (1513 tarihli).

TSMA.d.9772 (1518 tarihli?).

1.2.Tapu Kadastro Genel Müdürlüğ̈̈ Kuyûd-ı Kadîme Arşivi (TKA):

TKA.İ.363 (1555 tarihli).

TKA.TTD.172 (1555 tarihli).

1.3.Vakıflar Genel Müdürlüğü Arşivi

VGMA.d. 596, Sahife 67. 1574 yılı Ağustos ayı sonları (Evâsıt-1 C. Evvel 982) tarihli Murad Paşa Vakfiyesi.

\section{Yayınlanmış Arşiv Kaynakları}

BOA (1995). 166 Numaralı Muhâsebe-i Vilâyet-i Anadolu Defteri (937/1530), <Dizin ve Tipkıbasım>. Haz. A. Özkılınç, A. Coşkun, M. Karazeybek, A. Sivridağ \& M. Yüzbaşığlu. Ankara 1995.

Erdoğru M. A. (2013). Ala‘iyye Sancağı - 1475 Tarihli Suret-i Defter-i İcmâl-i Vilâyet-i Ala‘iyye (Metin ve İnceleme). Yay. Haz. F. N. Koçak. Konya 2013.

Gökçe T. (1994). “Anadolu Vilâyetine Dair 919 (1513) Tarihli Bir Kadı Defteri”. Tarih İncelemeleri Dergisi 9/1 (1994) 215-259.

\section{Kanunnâmeler}

Kanunnâme-i Sultan Süleyman Han (1522 tarihli). Beyazıt Kütüphanesi. Veliyüddin Efendi Kitaplığı. No.1969.

\section{Kaynak Eserler}

Celalzâde Mustafa (1981). Tabakâtül-Memâlik ve Derecâtü'l-Mesâlik. Neşr. P. Kappert. Wiesbaden 1981.

Celalzade Mustafa Çelebi (2011). Muhteşem Çağ Kanuni Sultan Süleyman - Tabakâtül-Memâlik ve Derecâtü'l-Mesâlik. Haz. A. Yılmaz. İstanbul 2011.

Feridun Bey (1274). Mecmu'a-i Münşe 'atü's-Selâtîn I. İstanbul 1274.

Haydar Çelebi (1984). Haydar Çelebi Ruznâmesi. Haz. Y. Senemoğlu. İstanbul 1984.

Mehmed Süreyya (1311). Sicill-i Osmani III. İstanbul 1311.

Mehmed Süreyya (1996). Sicill-i Osmanî-Osmanlı Ünlüleri 5. Yay. Haz. Nuri Akbayar. İstanbul 1996.

Peçevî İbrahim Efendi (1283). Peçevî Tarihi I. İstanbul 1283.

Peçevî İbrahim Efendi (1999). Peçevî Tarihi I. Haz. B. S. Baykal. İstanbul 1999.

\section{Tetkik Eserler}

Akgül M. (1989). 16. Yüzyll Arşiv Kayıtlarına Göre Alâiyye'nin Sosyal ve Ekonomik Hayatı ile Nüfus ve İdari Taksimatı. Yayımlanmamış Doktora Tezi. İstanbul Üniversitesi, İstanbul 1989. 
Akgündüz A. (1991). Osmanlı Kanunnâmeleri ve Hukuki Tahlilleri III. İstanbul 1991.

Armağan A. L. (1998). "XVI. Yüzyılda Teke Sancağındaki Konar - Göçerlerin Demografik Durumu Üzerine Bir Araştırma”. Tarih Araştırmaları Dergisi 19/30 (1998) 1-35.

Barkan Ö. L. (2000). “H.933-934 Tarihli Bütçe Cedveli ve Ekleri”. Yay. Haz. H. Özdeğer, Osmanlı Devleti'nin Sosyal ve Ekonomik Tarihi Tetkikler-Makaleler I (2000) 649-702.

Baykara T. (2000). Anadolu'nun Tarihi Coğrafyasına Giriş I - Anadolu’nun İdari Taksimatı. Ankara 2000.

Bulduk Ü. (2013). XVI. Asırda Karahisar-ı Sahip (Afyonkarahisar) Sancağı. Ankara 2013.

Çakar E. (2002). “Kanuni Sultan Süleyman Kanunnâmesine Göre 1522 Y1lında Osmanlı İmparatorluğu'nun İdari Taksimatı". Firat Üniversitesi Sosyal Bilimler Dergisi 12/1 (2002) 261-282.

Çakar E. (2003). "XVI. Yüzyılda Şam Beylerbeyliğinin İdarî Taksimatı". Fırat Üniversitesi Sosyal Bilimler Dergisi 13/1 (2003) 351-374.

Emecen F. M. (1989). XVI. Asırda Manisa Kazası. Ankara 1998.

Emecen F. M. (2015). “'İhtilalci Bir Mehdilik’ Hareketi Mi? Şahkulu Baba Tekeli İsyanı Üzerine Yeni Yaklaşımlar”. Ed. A. Koçal \& Z. Berktaş, Ötekilerin Peşinde Ahmet Yaşar Ocak'a Armağan (2015) 521534. İstanbul.

Erdoğru M. A. (1998). Osmanlı Yönetiminde Beyşehir Sancă̆ (1522-1584). İzmir 1998.

Ergenç Ö. (1995). Osmanlı Klasik Dönemi Kent Tarihçiliğine Katkı: XVI. Yüzyılda Ankara ve Konya. Ankara 1995.

Erten F. (1340). Antalya Livası Tarihi. İstanbul 1340.

Gökbilgin M. T. (1956). "Kanuni Sultan Süleyman Devri Başlarında Rumeli Eyaleti Livaları, Şehir ve Kasabaları”. Belleten XX/78 (1956) 247-294.

Göyünç N. (1969). "Diyarbekir Beylerbeyliğinin İlk İdari Taksimatı”. Tarih Dergisi XXIII/Mart (1969) 23-34.

İlgürel M. (2001). "Kalender Şah”. DİA 24 (2001) 249.

İnalcık H. (2005). Osmanlı Imparatorluğu Klâsik Çăg (1300-1600). Çev. R. Sezer. İstanbul 2005.

Kankal A. (2009). XVI. Yüzyılda Çankırı. Çankırı 2009.

Karaca B. (1999). “XVI. Asırda Teke Yöresinden Kıbrıs'a Yapılan Sürgünler”. Ed. G. Eren. Osmanlı IV (1999) 649-652.

Karaca B. (2002a). XV ve XVI. Yüzyıllarda Teke Sancă̆ı. Isparta 2002.

Karaca B. (2002b). "Safevi Devleti'nin Ortaya Çıkışı ve II.Bayezid Dönemi Osmanlı-Safevi İlişkileri”. Ed. H. C. Güzel, K. Çiçek \& S. Koca, Türkler IX (2002) 409-418. Ankara.

Karaca B. (2009). XV. ve XVI. Yüzyıllarda Manavgat Kazası. Isparta 2009.

Karaca B. (2010). “Dünden Bugüne Manavgat”. Ed. A. K. Atılgan, Dünden Bugüne Antalya (2010) 423446. Antalya.

Karaca B. (2017). “Teke Yöresinden Safevi Devletine Göçler”. Ed. O. Köse, Geçmişten Günümüze Göç I (2017) 569-585. Samsun.

Konyalı İ. H. \& Yıldız A. (2010). Abideleri ve Kitabeleri ile Manavgat Tarihi. Antalya 2010.

Konyalı İ. H. (2011). Alanya (Alâiyye). İstanbul 2011.

Kunt İ. M. (1978). Sancaktan Eyâlete 1550-1650 Arasında Osmanlı Ümerası ve İl İdaresi. İstanbul 1978.

Miroğlu İ. (1990). Kemah Sancă̆ı ve Erzincan Kazâst. Ankara 1990.

Öz M. (2010). “Tahrir”. DIA 39 (2010) 425-429. Ankara.

Selekler M. (2011). Yarım Asrın Arkasından Antalya'da Kemer, Melli, İbradı ve Serik. Yay. Haz. A. Yıldız \& R. Kaya. Antalya 2011.

Seslikaya A. (2014). Yavuz Sultan Selim'in Sefer Menzilnâmeleri (Çaldıran, Kemah, Dulkadiroğlu ve Misır Seferi Menzilnâmeleri) ve Haydar Çelebi Ruznâmesi: Transkripsiyon ve Değerlendirme. Yayımlanmamış Yüksek Lisans Tezi. Gaziosmanpaşa Üniversitesi, Tokat 2014.

Sümer F. (1976). Safevi Devleti’nin Kuruluşu ve Gelişmesinde Anadolu Türklerinin Rolü. Ankara1976.

Tekindağ Ş. (1967-1968). "Şah Kulu Baba Tekeli İsyanı”. Belgelerle Türk Tarih Dergisi I/3 (1967) 34-39; I/4 (1968) 54-59.

Tekindağ Ş. (1979). “Teke-eli veya Teke-ili”. İA XII/I (1979) 124-128. 
Ünal M. A. (2014). Osmanlı Devrinde Sinop. Ankara 2014.

Varlık M. Ç. (1999). “Anadolu Eyaleti Kuruluşu ve Gelişmesi”. Ed. G. Eren, Osmanlı 6 (1999) 123-129. Ankara.

Yörük (2012). “Osmanlı Döneminde Alâiyye Sancağı’nın İdari Yapısı”. Ed. F. N. Koçak, Alanya XII.Tarih ve Kültür Sempozyumu (2012) 270-291. Konya.

Yücel Y. (1974). “Osmanlı İmparatorluğu'nda Desantralizasyona (Adem-i Merkeziyet) Dair Genel Gözlemler”. Belleten XXXVIII/152 (1974) 657-708. 
